\title{
Impacts of Climate Change on Irrigation Water Demand of Paddy: A Case Study from Hakwatuna Oya Irrigation Scheme in Sri Lanka
}

\author{
M. Rajendran ${ }^{*}$, E.R.N. Gunawardena ${ }^{1}$ and N.D.K. Dayawansa ${ }^{1}$ \\ Postgraduate Institute of Agriculture \\ University of Peradeniya \\ Sri Lanka
}

\begin{abstract}
Assessment of irrigation water requirement (IWR) is a prerequisite for planning and management of an irrigation scheme, particularly for a water short scheme. In this context, this study was conducted to estimate the current and future IWR under A2 (very heterogeneous world) and B2 (world in which emphasis is on local solutions to economic, social, and environmental sustainability) scenarios of IPCC emission for Hakwatuna Oya irrigation scheme using SDSM and CROPWAT models. It was found that the reference evapotranspiration (ETo) during Maha and Yala seasons at present are $407 \mathrm{~mm}$ and 506 $\mathrm{mm}$, respectively. Water requirement of $3^{1 / 2}$ months paddy in Maha season is 1,282 $\mathrm{mm}$ whereas it is $1,381 \mathrm{~mm}$ in Yala season. The crop water requirement, which depends primarily on temperature, remains relatively stable over the simulation period up to 2070. When compared to the mean annual rainfall during 1972 to 2001, the rainfall is expected to increase by 32\% and 27\% from 2041 to 2070 under A2 and B2 scenarios, respectively. As a result, the total water availability from rainfall and irrigation water issues from the Hakwatuna Oya reservoir in Maha season would increase in the future with an overall water deficit to reduce from $28 \%$ to $18 \%$ and from $28 \%$ to $20 \%$ under A2 and B2 scenarios, respectively. For Yala season, this reduction is found to be $30 \%$ to $24 \%$ and $30 \%$ to $26 \%$ under $A 2$ and $B 2$ scenarios, respectively. The benefits from climate change could be further enhanced by adjusting the planting time to coincide with months of high rainfall.
\end{abstract}

Keywords: Climate change, CROPWAT, irrigation water requirement, SDSM

\section{INTRODUCTION}

Rice is the staple food crop of Sri Lanka. Approximately 1.8 million farm families are engaged in paddy cultivation island-wide, which is grown on $34 \%$ of total cultivated area in Sri Lanka (DOA, 2006). Approximately $44 \%$ of the paddy is irrigated under major irrigation schemes and $24 \%$ is irrigated under minor irrigation schemes (Aheeyar, 2012) during two main cropping seasons associated with rainfall. The Second Inter Monsoonal (SIM) and North East Monsoon (NEM) rainfall seasons together forms major cultivation season known as "Maha" (September- February) while the First Inter Monsoonal (FIM) and South West Monsoon (SWM) collectively forms the minor cultivation season recognized as "Yala" (March - August) (Chithranayana and Punyawardena, 2007). Agriculture is the highest water

\footnotetext{
1 Department of Agricultural Engineering, Faculty of Agriculture, University of Peradeniya, Sri Lanka

* Author of correspondence : rajanv.puram@yahoo.com
} 
use sector in Sri Lanka which accounts for 96\% of the water withdrawals in 1991 (Amarasinghe et al., 1999).

Sri Lanka's rice demand is projected to increase by about 35\% in 2020 (Aheeyar, 2012) and much of this increase will rely on irrigation water supply. In many parts of the country, productivity of the rice is below optimal levels due to insufficient irrigation water supplies. Further, there is a perception among many stakeholders including farmers that climate change would further aggravate water scarcity issues in irrigation systems as indicated by results of several research studies (Vairamoorthy et al., 2008; Schewe et al., 2014; Perera, 2015). The biggest challenge is, therefore, to produce more food with less water in order to meet the rising food demand.

Implementation of best management strategies is vital for efficient irrigation water use to maximize production per unit of water being used. Accurate planning and delivery of the necessary amount of water in time and space can conserve water (Bos et al., 2009). Therefore, estimation of crop water requirement (CWR) is a prerequisite for project planning, designing and management of irrigation systems (Rowshon et al., 2014; Othman and Dahim, 2016). CROPWAT is a practical tool which can be used to estimate evapotranspiration and crop water requirement, and more specifically to design and management of irrigation schemes (Smith, 1992). Surface air temperature and rainfall are the two key climatic variables that influence CWR (Esham and Garforth, 2013), and the variability of these parameters has implications on both agriculture and water resources. The impacts of variability in temperature and rainfall are severe on rice cultivation as it requires large quantity of water. A number of researchers have studied the impact of climate change on irrigation water demand (Shahid, 2010; Shen et al., 2013; Zainal et al., 2014). Therefore, in addition to estimating current irrigation water requirement (IWR), it is necessary to estimate future irrigation water requirement so that strategies could be formulated in advance to address the water scarcity issues to minimize the negative impacts on farming community. The Hakwatuna Oya irrigation scheme is one of the water deficit schemes in Kurunagella district. The contribution from rainfall and irrigation water is not adequate to cultivate both seasons and hence the cropping intensity is less than 2 in almost all years. Frequent crop failure, abandoning of cultivation seasons and reduced crop yields are the common issues which affect the livelihoods of nearly 2178 farming families. The above issues are mainly due to climate variability and inappropriate irrigation water management decisions. Further, there are no detailed studies on long-term climate change in order to quantify future water availability and irrigation water demand in this region. With this background, a study was conducted to predict the impact of climate change with respect to temperature and rainfall on irrigation water demand in a selected major irrigation scheme in upper Deduru Oya basin.

\section{MATERIALS AND METHODS}

\section{Study area}

The Hakwatuna Oya irrigation scheme is located in the North Western Province of Sri Lanka. The latitude and longitude of this watershed are $7.77^{\circ} \mathrm{N}$ and $80.46^{\circ} \mathrm{E}$, respectively. The Hakwatuna Oya reservoir supplies water to Right Bank (RB) and Left Bank (LB) canals in order to supplies water to an extent of 2,578 ha of command area (Fig. 1). This Irrigation scheme is in the IL3 agro ecological region and receives an expected annual rainfall of more 
than 1,100 mm (Punyawardena, 2008). The main rice growing soils in this region are Reddish Brown Earth, Low Humic Glay and Non Calcic Brown soils situated in an undulating terrain (DOA, 2006; Punyawardena, 2008).

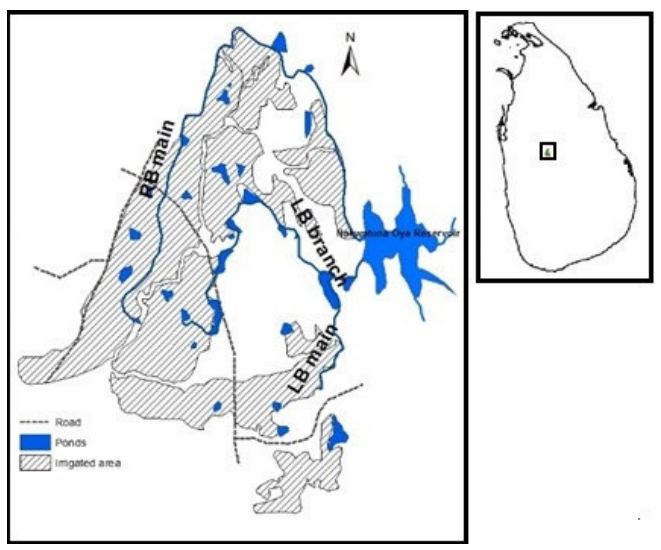

Fig. 1. Location and irrigation canals of the Hakwatuna Oya irrigation scheme

\section{Modelling climate scenarios and irrigation water demand}

Different methods have been used to simulate future climate scenarios. Statistical downscaling (SD) method is one of the widely used methods to project future climate scenarios (Tukimat and Harun, 2012; Behera et al., 2016) as it gives more promising options in situations where low cost, rapid assessments of localized climate change impacts are required (Wilby et al., 2002). In this study, statistical downscaling model (SDMS) was used to generate future climate scenarios while CROPWAT model was used to estimate current and future crop water demand. Fig. 2 illustrates the overall modelling process used in this study.

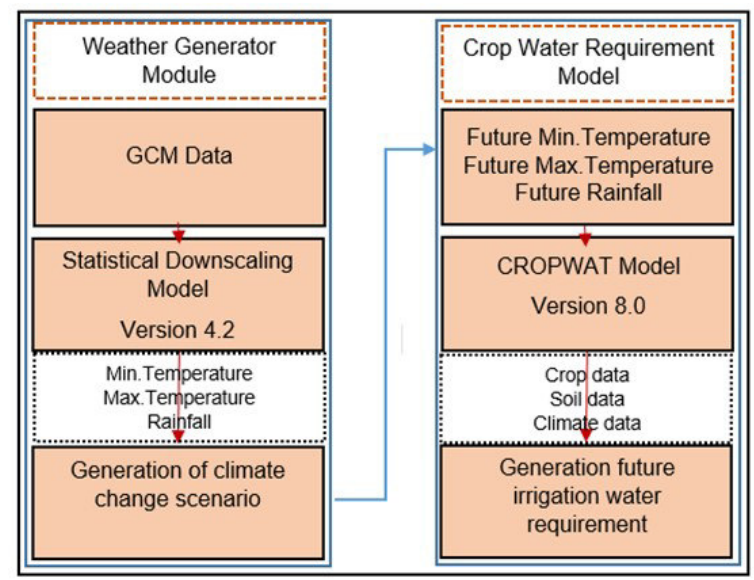

Fig. 2. Overall modelling process for generation of climate change scenario and assessment of future irrigation water demand Statistical Downscaling Model (SDSM) 
SDSM is a decision support tool that facilitates rapid development of multiple, low-cost, single-site scenarios of daily surface weather variables such as temperature and rainfall under current and future regional climate (Wilby et al., 2002). It uses linear regression techniques between predictors (observed large scale climate fields) and predictands (local observed meteorological variables) to produce multiple realizations (ensembles) of synthetic daily weather sequences. The predictor variables provide daily information about large scale atmospheric condition, while the predictand describes the condition at the site level (Bekele, 2009).

\section{Calibration and validation}

SDSM 4.2 model was used to develop future temperature and rainfall scenarios at a monthly scale. For this analysis, predictand data (daily minimum and maximum temperature recorded at Batalagoda Rice Research Station, and daily rainfall recorded at Maho for the period from1972 to 2001) were collected from Natural Resources Management Centre (NRMC) of the Department of Agriculture. Two climate predictors, the National Centers Environmental Prediction (NCEP) and GCMs at the grid box of $28 \mathrm{X} \times 39 \mathrm{Y}$ were downloaded and the downscaling predictor variables were selected for each predictand based on correlation analysis of observed data and NCEP predictors. Variables with higher correlation coefficients between predictands and predictors were chosen for model calibration and validation. Daily climate data from 1972-1986 and 1987 to 2001 were used for model calibration and validation processes, respectively.

\section{Model performance evaluation}

The model performance was evaluated by the coefficient of determination ( $\left.\mathrm{iR}^{2}\right)$, NashSutcliffe Coefficient (NSE), Percent bias (PBIAS) and RMSE-observations and Standard Deviation Ratio (RSR) methods. In general, $\mathrm{iR}^{2}$ value is used as an indicator of the strength of relationship between the observed and simulated values while NSE indicates how precisely the plot of observed versus simulated values fits the line (Moriasi et al., 2007).

\section{Scenario generation using HadCM3 predictors}

The calibrated SDSM model was applied to generate future climate scenarios for temperature and rainfall at a monthly scale under both HadCM3 A2 $2^{2}$ and HadCM3 B2 ${ }^{3}$ storylines. HadCM3 was chosen because of its wide application in many climate change studies (Basnayake and Vithanage, 2004; De Silva, 2006; Behera et al., 2016). Hundred (100) ensembles of synthetic daily time series were produced for HadCM3 for 128 years (1972 to 2099) for minimum and maximum temperatures, and rainfall. Three periods namely, current (1972-2001), 20s (2011-2040) and 50s (2041-2070) were used for trend analysis. The SDSM modelling process used is given in Fig. 3.

\footnotetext{
${ }^{2}$ A very heterogeneous world with continuously increasing global population and regionally oriented economic growth that is more fragmented and slower than in other storylines.

${ }^{3}$ A world in which the emphasis is on local solutions to economic, social and environmental sustainability, with continuously increasing population (lower than A2) and intermediate economic development.
} 


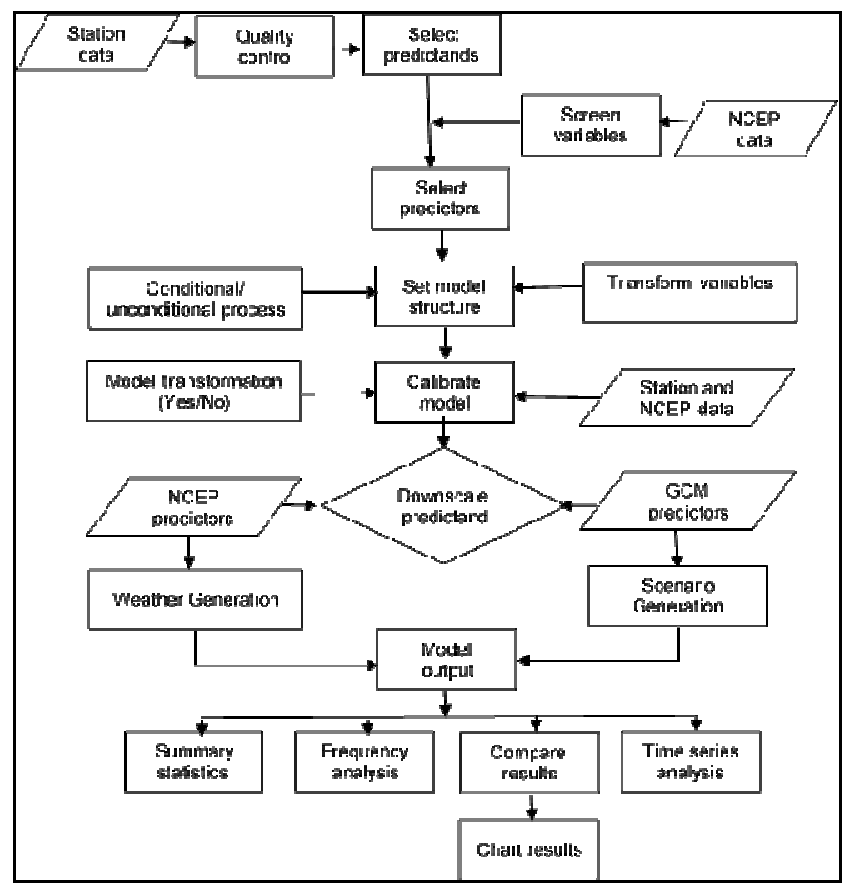

Fig. 3. SDSM scenario generation for HadCM3 model (scenario A2 and B2)

\section{CROPWAT model}

CROPWAT is a DOS or Windows based decision support system designed as a tool to help agro-meteorologists, agronomists, and irrigation engineers to carry out standard calculations for evapotranspiration and crop water use studies, particularly the design and management of irrigation schemes. This model was developed by the Land and Water Development Division of FAO (Smith, 1992) which calculates reference evapotranspiration (ETo), CWR and IWR using existing or new climatic, soil and crop data. It uses Penman-Monteith methods to calculate ETo. Further the model allows the development of recommendations for improved irrigation practices, planning of irrigation schedules under varying water supply conditions, and assessment of production under rainfed conditions or deficit irrigation (Smith, 1992).

In the present study, CROPWAT 8.0 was applied to estimate ETo under simulated climate scenarios. Meteorological parameters such as latitude, longitude and altitude of the study area, wind speed and sunshine hours for the period from 2000-2014 were collected from NRMC. In this study, CWR was estimated for $3 \frac{1}{2}$ months of rice variety as it is the main crop grown in this study area. Crop coefficient values $(\mathrm{Kc})$ for different growth stages were taken from available published data. Paddy irrigation water requirement (IWR) was estimated using Equation 1.

$\mathrm{IWR}=\mathrm{ET}_{\text {crop }}+\mathrm{W}_{\mathrm{lp}}+\mathrm{W}_{\mathrm{ps}}+\mathrm{W}_{1}-\mathrm{P}_{\mathrm{e}}$

where; IWR is the irrigation water requirement; $\mathrm{ET}_{\text {crop }}$ is the crop evapotranspiration; $\mathrm{W}_{\mathrm{lp}}$ is the water required for land preparation; $\mathrm{W}_{\mathrm{ps}}$ is the percolation and seepage losses; $\mathrm{W}_{1}$ is the water required to establish standing water layer for paddy; $P_{e}$ is the effective rainfall. $W_{l p}$, 
$\mathrm{W}_{\mathrm{ps}}$ and $\mathrm{W}_{1}$ for Hakwatuna Oya irrigation scheme were collected from the Irrigation Department, Kurunagella while $\mathrm{ET}_{\text {crop }}$ and $\mathrm{P}_{\mathrm{e}}$ were estimated using CROPWAT model.

\section{Seasonal water requirement}

Rainfall and irrigation water issued from the Hakwatuna Oya reservoir was collected for the period from 1994 to 2010 to estimate the relative contribution to satisfy the irrigation water demand, estimated using Equation 1. The years in which the entire crop was failed or the cultivation was abandoned were removed from the analysis. The water deficit during current (1972-2001), 20s (2011-2040) and 50s (2014-2070) under two scenarios (A2 and B2), was estimated to find the impact of climate change on irrigation water demand.

\section{RESULTS AND DISCUSSION}

\section{Developing climate scenarios}

\section{Calibration and Validation of SDSM model}

Fig. 4 shows calibration (1972-1986) and validation (1987-2001) results of maximum and minimum temperatures, and rainfall. There is a good agreement between observed and downscaled climate parameters during both calibration and validation periods.

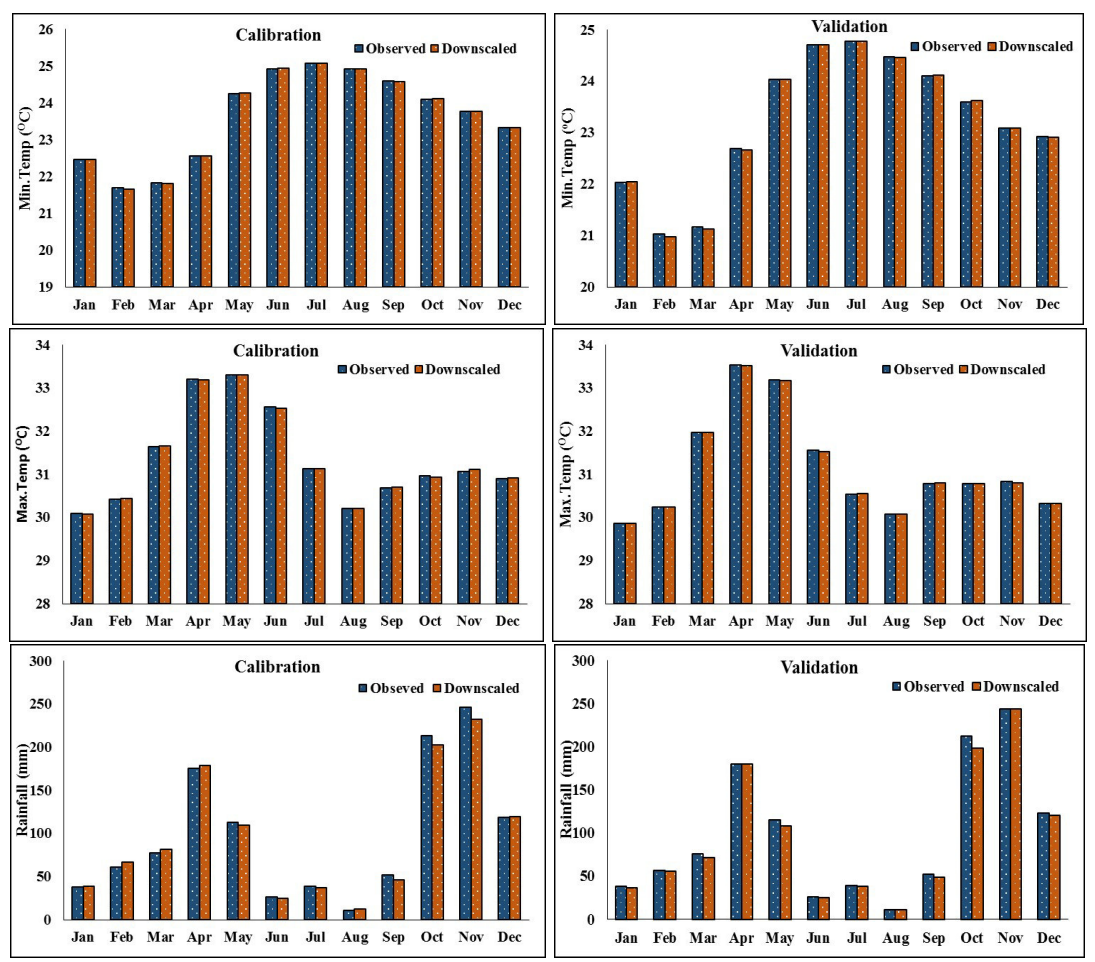

Fig. 4. Calibration (1972-1986) and Validation (1987-2001) outputs of SDSM model 
Table 1 shows the values of selected statistical performance indices. Better model performance can be realized if the NSE and $\mathrm{iR}^{2}$ are closer to unity and RSR and PBIAS have smaller values (Golmohammadi et al., 2014). According to Moriasi et al. (2007), performance of model is considered as good if NSE $\geq 0.65$, PBIAS $\leq \pm 15 \%$ and RSR $\leq 0.60$. Accordingly, this model is calibrated well and can be used for scenario generation.

Table 1. Calibration and validation statistics of SDSM modelling

\begin{tabular}{cllccc}
\hline Model & & NSE & RSR & PBIAS (\%) & $\mathrm{R}^{2}$ \\
\hline \multirow{2}{*}{ Min.Temp. } & Calibration & 0.99 & 0.01 & 0.02 & 0.99 \\
& Validation & 0.99 & 0.02 & 0.03 & 0.99 \\
\multirow{3}{*}{ Max.Temp. } & Calibration & 0.99 & 0.02 & 0.01 & 0.99 \\
\multirow{3}{*}{ Rainfall } & Validation & 0.99 & 0.02 & 0.02 & 0.99 \\
& Calibration & 0.99 & 0.08 & 1.80 & 0.99 \\
& Validation & 0.99 & 0.06 & 2.84 & 0.99 \\
\hline
\end{tabular}

\section{Future scenario generation}

The calibrated SDSM model was used to generate the future downscaled data (temperature and rainfall) under A2 and B2 scenarios of IPCC. The study showed an increase in annual mean maximum and minimum temperatures under both scenarios. Previous studies conducted in Sri Lanka (Fernando and Chandrapala, 1992; De Costa, 2008; Amaraweera, 2014) have also shown a general warming. Fig. 5 shows how monthly mean maximum and minimum temperatures, and rainfall vary with reference to current climate scenario (19722001) under A2 and B2 storylines.
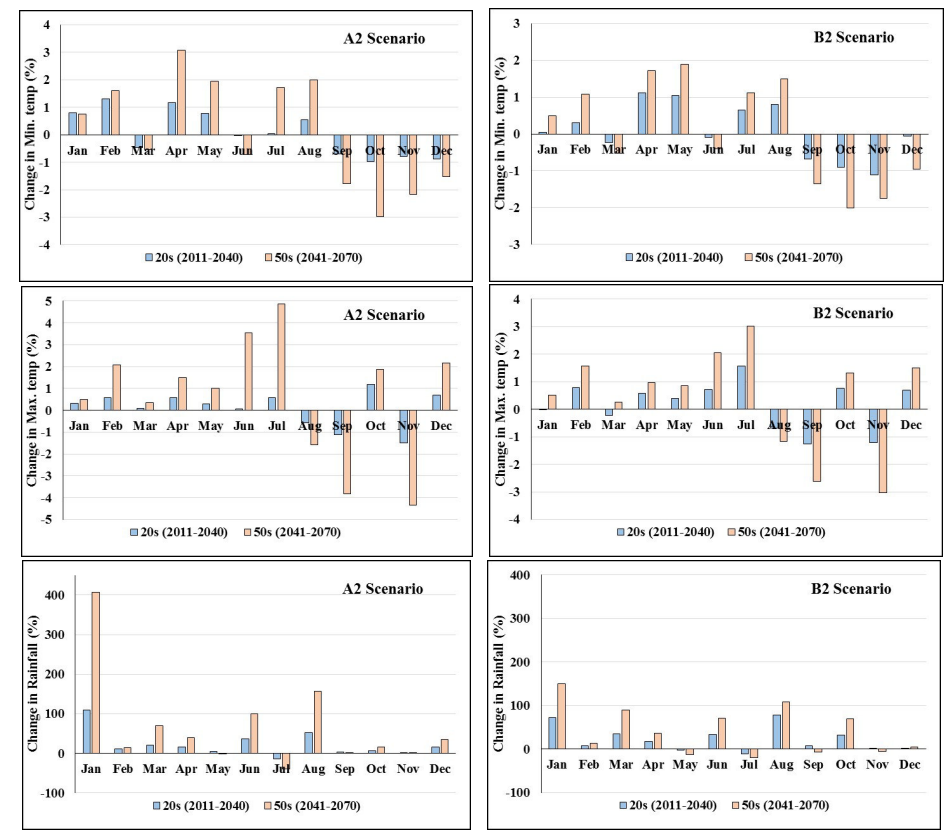

Fig. 5. Monthly variation (\%) of future temperature and rainfall with reference to current scenario (1972-2001) 
The study predicts that the minimum temperature will reduce from September to December and in the months of March and June whereas maximum temperature is expected to decrease in the months of August, September and November under both scenarios. Further, mean monthly rainfall is expected to decrease in the months of July whereas a substantial increase is projected in January, March, June and August in future; the overall increase is higher under A2 scenario.

Table 2 shows the seasonal changes of monthly mean minimum and maximum temperatures and total rainfall with reference to current scenario (1972-2001). Accordingly, mean minimum temperature is expected to decrease in Maha season (Sep-Feb); on the other hand, an increase is expected in Yala season (Mar-Aug). The mean maximum temperature will increase during both Maha and Yala seasons in future under both A2 and B2 scenarios.

Table 2. Seasonal changes of climate parameter under $A 2$ and $B 2$ scenarios

\begin{tabular}{llcccc}
\hline \multirow{2}{*}{ Description } & \multicolumn{4}{c}{ Scenarios } \\
\cline { 3 - 6 } & Season & $20 \mathrm{~s}$ & $50 \mathrm{~s}$ & $20 \mathrm{~s}$ & $\mathrm{~A} 2 \mathrm{~s}$ \\
\cline { 2 - 6 } & Maha & -0.03 & -0.21 & -0.10 & -0.16 \\
\hline Mean & Yala & +0.12 & +0.39 & +0.17 & +0.28 \\
Min.Temp. $\left({ }^{\circ} \mathrm{C}\right)$ & Maha & +0.08 & +0.14 & +0.07 & +0.13 \\
\hline Mean & Yala & +0.06 & +0.60 & +0.16 & +0.37 \\
Max.Temp. $\left({ }^{\circ} \mathrm{C}\right)$ & Maha & +80 & +224 & +90 & +182 \\
\hline \multirow{2}{*}{ Total Rainfall $(\mathrm{mm})$} & Yala & +66 & +158 & +80 & +140 \\
\hline
\end{tabular}

$(+)$ ve values indicates the expected increase while (-)ve values indicates the expected decrease of climate parameters with reference to current values.

Mean Annual Rainfall (MAR) is expected to increase by $12 \%$ (A2) and 14\% (B2) in 2020s while increase will be $32 \%$ (A2) and $27 \%$ (B2), respectively by 2050 s. The studies conducted by Basnayake et al. (2004) and De Silva (2006) also show an increase in MAR in Sri Lanka. Rainfall during Maha season is expected to increase by $12 \%$ (A2) and $13 \%$ (B2) in $2020 \mathrm{~s}$, and $33 \%$ (A2) and $27 \%$ (B2) in 2050 s in the study area. The expected increases during Yala season will be $13 \%$ (A2) and $15 \%$ (B2) in 2020s, and $30 \%$ (A2) and $26 \%$ (B2) in 2050s. Further, both North East Monsoon (NEM) rainfall and South West Monsoon (SWM) rainfall are expected to increase under both scenarios. Findings are in agreement with results obtained by Basnayake and Vithanage (2004) who projected an increase in NEM and SWM rainfalls. Further, heavy rain is expected during NEM and SWM period, especially in January and August under A2 and B2 scenarios. Increased occurrence of extreme rainfall events is a common feature of the climate of Sri Lanka during recent decades due to climate change (Punyawardena, 2012).

\section{Estimation of crop water requirement}

\section{Reference crop evapotranspiration (ETo)}

Evapotranspiration rate from a reference surface, not short of water, is called the reference crop evapotranspiration (ETo) or reference evapotranspiration (FAO, 1998). Daily ETo ranges between $4.8 \mathrm{~mm} /$ day and $3.3 \mathrm{~mm} /$ day for May and December, respectively (Fig. 6). A 
slight increase, except September and November, in ETo is expected under A2 and B2 scenarios. A total ETo of $407 \mathrm{~mm}$ and $506 \mathrm{~mm}$ were observed in Maha and Yala cultivation seasons, respectively. Although a slight increase in seasonal ETo is expected in future under both scenarios, the variation is not significant.
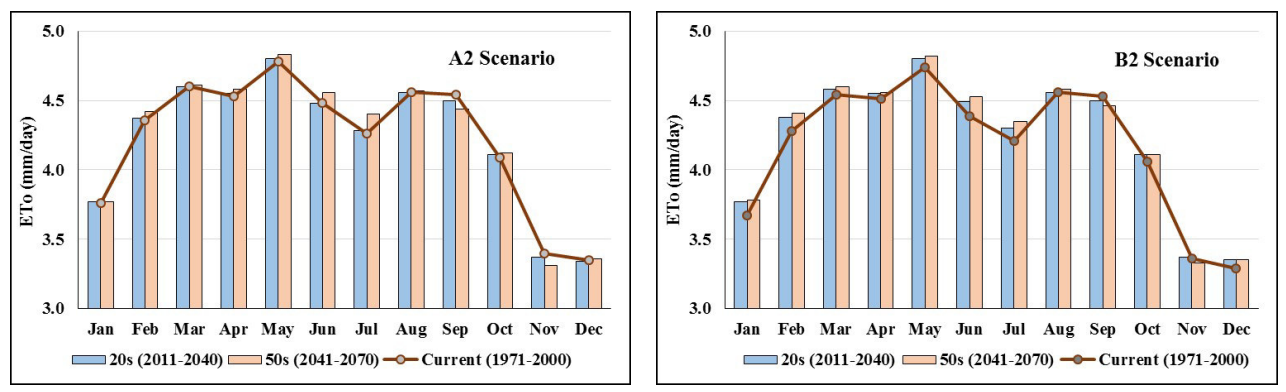

Fig. 6. Reference crop evapotranspiration (ETo) under A2 and B2 scenarios

\section{Seasonal water requirement of paddy}

Total water requirement of paddy during Maha and Yala cultivation seasons were determined using Eq.(1). It was found that the total water requirement of paddy ( $3 \frac{1}{2}$ months) in the study area in Maha season is 1,282 $\mathrm{mm}$ whereas it is $1,381 \mathrm{~mm}$ in Yala season. These results are in agreement with the values obtained by Rathnayake (2011) who reported that the CWR of paddy are 1,300 $\mathrm{mm}$ and 1,375 $\mathrm{mm}$ in Maha and Yala seasons, respectively. The estimated CWR are expected to be the same in future since there will be a little variation in temperature and hence the ETo. However, irrigation water requirement (IWR) is expected to decrease in future due to incresed rainfall (Fig. 7). The projected decrease in Maha season will be $6 \%(\mathrm{~A} 2)$ and $7 \%(\mathrm{~B} 2)$ in $2020 \mathrm{~s}$ and $15 \%$ (A2) and $13 \%(\mathrm{~B} 2)$ in $2050 \mathrm{~s}$. The decrease in Yala season will be 5\% - 3\% in 2020s and 7\% - 5\% in 2050s under A2 and B2 scenarios, respectively.
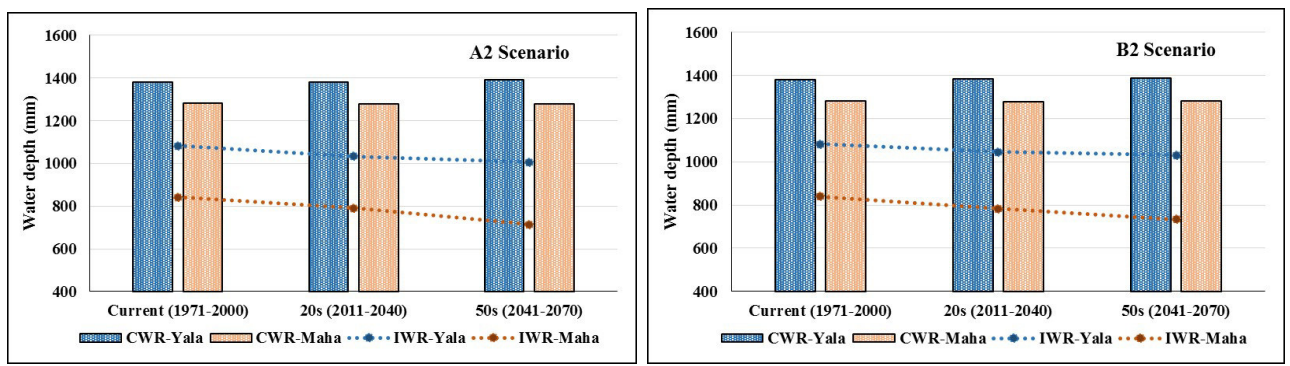

Fig. 7. Seasonal CWRs and IWRs of paddy under A2 and B2 scenarios

Fig. 8 shows monthly variations of IWR under current and future climatic scenarios. Accordingly, irriation water requirement in the months of January, April, June and December is expected to reduce slightly in 2020s and 2050s under both A2 and B2 scenarios. However, a slight increase is projected in the month of July. 

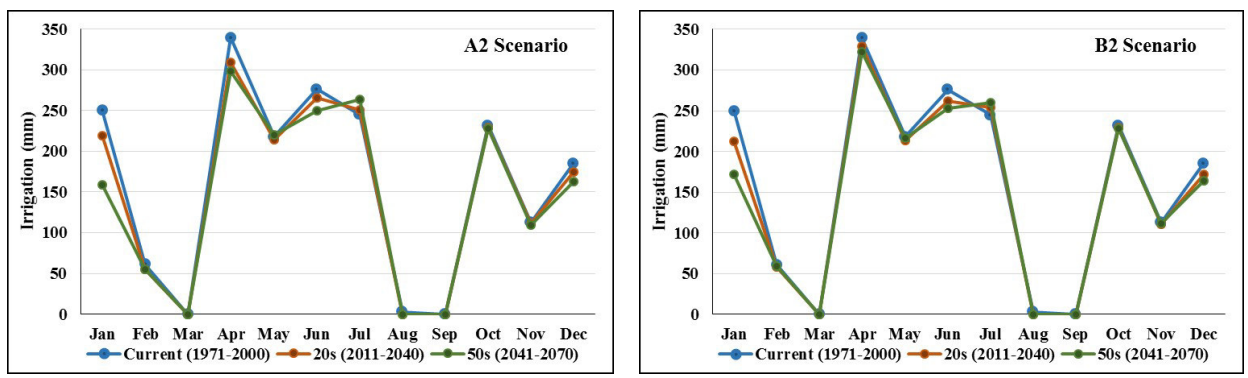

Fig. 8. Variation of monthly IWR under A2 and B2 Scenarios

\section{Current and future contribution of rainfall for crop production}

The Hakwatuna Oya irrigation scheme is a water deficit system, where unmet demand is significant. Fig. 9 shows CWR and water supply during Maha and Yala seasons over the recent past. Within the last 15 years, some seasons were abandoned, particularly 1996 and 1997 Yala seasons and 2000/2001 Maha season, due to insufficient water. Crop failures were experienced in 2000 and 2002 Yala and in 2008/2009 Maha seasons. Crop yields were also low due to water stress, especially during critical growing periods. Further, in general, this system is unable to supply irrigation water for the entire command area.

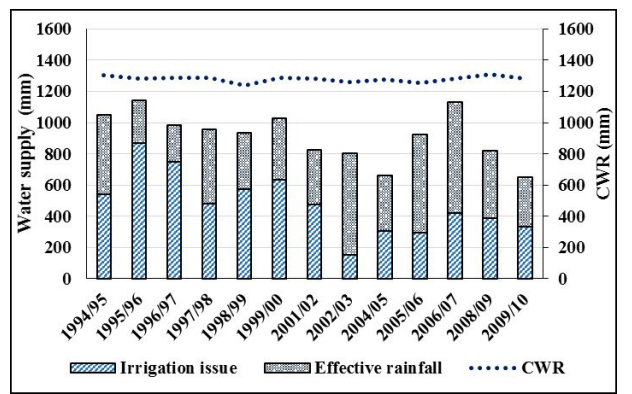

(a)

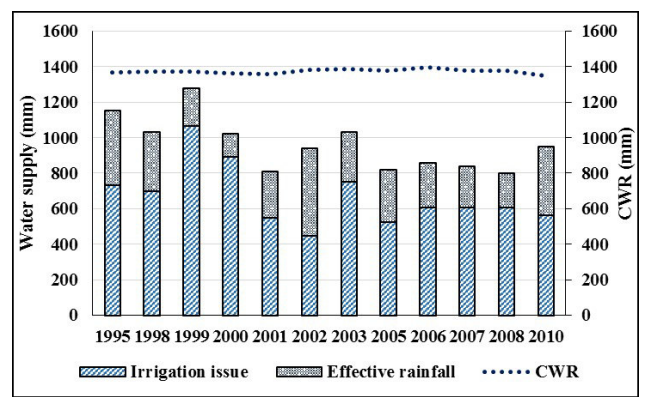

(b)

Fig. 9. Scheme water supply and CWR for Maha (a) and Yala (b) seasons

At present, rainfall contributes around 34\% and 22\% of CWR in Maha and Yala seasons, respectively (Table 3 ). The projected rainfall would contribute $38 \%$ (A2) and $39 \%$ (B2) of CWR in 2020s, and 44\% (A2) and 43\% (B2) of CWR in 2050s in Maha season. The expected rainfall increase would satisfy $25 \%$ (A2) and $24 \%$ (B2) of CWR in 2020 s and $28 \%$ (A2) and 26\% (B2) in 2050s in Yala season.

Further, the current water deficit (difference between CWR of cultivated area and water supplied by irrigation and rainfall) in Maha and Yala seasons are $28 \%$ and $30 \%$, respectively. However, a slight decrease is expected in future; about $24 \%$ in 2020 s under A2 and B2 scenararios, and $18 \%$ (A2) and 20\% (B2) in 2050s in Maha season. Crop water deficit will be $26 \%-27 \%$ in 2020 s, and $24 \%-26 \%$ in 2050 s under A2 and B2 scenarios, respectively, in

Yala season. 
Table 3. Crop water requirement and water deficit under current and future scenarios

\begin{tabular}{llccccc}
\hline \multirow{2}{*}{ Season } & \multirow{2}{*}{ Description } & \multicolumn{3}{c}{ A2 } & \multicolumn{3}{c}{ B2 } \\
\cline { 3 - 7 } & & \multicolumn{3}{c}{ Scenarios } \\
\cline { 2 - 6 } Maha & Water requirement (mm) & 1282 & 1280 & 1279 & 1280 & 1280 \\
& Irrigation (mm)* & 478 & 478 & 478 & 478 & 478 \\
& Effective rainfall (mm) & 440 & 490 & 565 & 498 & 546 \\
& Contribution from rainfall (\%) & 34 & 38 & 44 & 39 & 43 \\
& Water deficit (\%) & 28 & 24 & 18 & 24 & 20 \\
\hline \multirow{5}{*}{ Yala } & Water requirement (mm) & 1381 & 1383 & 1390 & 1383 & 1387 \\
& Irrigation (mm)* & 670 & 670 & 670 & 670 & 670 \\
& Effective rainfall (mm) & 299 & 350 & 385 & 338 & 357 \\
& Contribution from rainfall (\%) & 22 & 25 & 28 & 24 & 26 \\
& Water deficit (\%) & 30 & 26 & 24 & 27 & 26 \\
\hline
\end{tabular}

*Assumption: Long term average irrigation issues for Maha and Yala seasons will not change in future. This is a safe assumption since increased rainfall would incrase the inflow to the researvoir and, hence, enhance the water availability for irrigation.

The results indicate that climate change is not going to aggravate the water scarcity problems in this irrigation scheme in contrast to the current perception among many stakeholders including farmers. The results are in agreement with the results of previous studies conducted in Sri Lanka. Although there is an increase in rainfall, water deficit is expected to be almost the same in the future in this study area. The overall benefits of climate change can be achived through effective use of enhanced rainfall, particularly in the months of March and August by adjusting planting time.

\section{CONCLUSIONS}

The results indicated that expected climate change in the study area would increase both annual rainfall and monthly mean temperature. However, this increase in temperature would not exceed $0.6{ }^{\circ} \mathrm{C}$ per day. Therefore, the crop water requirement, which depends primarily on temperature, is expected to remain relatively stable over the simulation period up to 2070 . The rainfall is expected to increase in Maha and Yala seasons up to 2070. The percentage increase of seasonal rainfall for Yala season would be $30 \%$ and $26 \%$ for A2 and B2 scenarios respectively, whilst it would be about $33 \%$ and $27 \%$ for $\mathrm{A} 2$ and $\mathrm{B} 2$ scenarios, respectively, for Maha season. As a result, the water deficit of Hakwatuna Oya irrigation scheme in Maha season would be reduced from $28 \%$ to $18 \%$ and from $28 \%$ to $20 \%$ under A2 and B2 scenarios, respectively. For Yala season, this reduction is found to be $30 \%$ to $24 \%$ and $30 \%$ to $26 \%$ under $\mathrm{A} 2$ and $\mathrm{B} 2$ scenarios, respectively. 


\section{ACKNOWLEDGEMENT}

This study was carried out with the aid of a grant from the International Development Research Centre (IDRC), Ottawa, Canada and their financial support is greatly acknowledged.

\section{REFERENCES}

Aheeyar, M.M.M. (2012). Climate change adaptation in water management for food security: Recent developments in Sri Lanka-A review of Existing Knowledge and Information. A report submitted to Sri Lanka Water Partnership \& Global Water Partnership -South Asia Colombo. 1-49p.

Amarasinghe, U.A., Mutuwatta, L. and Sakthivadivel. R. (1999). Water scarcity variations within a country: A case study of Sri Lanka. Research Report 32. Colombo, Sri Lanka: International Water Management Institute. 1-29p.

Amaraweera, P.H. (2014). Recent Trends of Minimum and Maximum Surface Temperatures over Sri Lanka. National Centre for Advanced Studies in Humanities and Social Sciences. Annual Research Symposium - 2014 - Symposium Proceedings. 121-127p.

Basnayake, B.R.S.B., Rathnasiri, J. and Vithanage, J.C. (2004). 'Rainfall and Temperature Scenarios for Sri Lanka under the Anticipated Climate Change'. Paper presented at the 2nd AIACC Regional Workshop for Asia and the Pacific, Manila, the Phillipines, 2-5 November 2004.

Basnayake, B.R.S.B. and Vithanage. J.C. (2004). Rainfall change scenarios for Sri Lanka under the anticipated climate change. Proceedings of the International Conference on Sustainable Water Resources Management in the Changing Environment of the Monsoon Region, Colombo, Sri Lanka, 1-8.

Behera,S., Khare, D., Mishra, P.K. and Sahoo, S. (2016). Application of Statistical Downscaling Model for Prediction of Future Rainfall in Bhudhabalanga River Basin, Odisha (India). International Journal of Engineering and Advanced Technology (IJEAT). 5(4), 24 30 .

Bekele, H.M. (2009). Thesis, "Evaluation of Climate Change Impact on Upper Blue Nile Basin Reservoirs", MSc Thesis, School of Post Graduate Studies, Arba Minch University, p.21.

Bos, M.G., Kselik, R.A.L., Allen, G.R. and Molden, D., (2009). Water Requirements for Irrigation and the Environment. Springer, p.172.

Chithranayana, R.D. and Punyawardena, B.V.R. (2008). Identification of drought prone agro-ecological regions in Sri Lanka: Journal of the National Science Foundation of Sri Lanka. 36(2), 117 - 123. 
De Costa, W.A.J.M. (2008). Climate change in Sri Lanka: Myth or reality? Evidence from long-term meteorological data, Journal of National Science Foundation, Sri Lanka 200836 Special Issue, 63-88.

De Silva, C.S. (2006). 'Impacts of Climate Change on Water Resources in Sri Lanka', Paper presented at the 32nd WEDC International Conference, Colombo, Sri Lanka.

DOA. (2006). Rice soils of Sri Lanka and their productivity. Available at http://www.doa.gov.lk/index.php/en/crop-recommendations/901. Accessed on 26.05.2016.

DOA. (2006). Rice. Available at http://www.doa.gov.lk/index.php/en/croprecommendations/808. Accessed on 10.06.2016.

Esham, M. and Garforth, C. (2013). Climate change and agricultural adaptation in Sri Lanka: a review. Climate and Development, 5 (1). pp. 66-76. ISSN 1756-5537 doi:10.1080/17565529.2012.762333.

FAO. (1998). Crop Evapotranspiration: Guidelines for Computing Crop Water Requirements. FAO Irrigation and Drainage Paper 56. Rome, Italy.

Fernando, T.K. and Chandrapala, L. (1992). Global Warming and Rainfall Variability - Sri Lankan Situation. Proceedings of the 47th Annual Session of Sri Lanka Association for the Advancement of Science (SLASS). Section El, 138p.

Golmohammadi, G., Prasher, S., Madani, A. and Rudra, R. (2014). Evaluating Three Hydrological Distributed Watershed Models: MIKE-SHE, APEX, SWAT. Hydrology, 2014, 1, 20-39; doi:10.3390/hydrology1010020.

Moriasi, D.N., Arnold, J.G., Van Liew, M.W., Bingner, R.L., Harmel, R.D. and Veith, T.L. (2007). Model evaluation guidelines for systematic quantification of accuracy in watershed simulations. American Society of Agricultural and Biological Engineers. 50(3), 885 - 900.

Othman, A.H. and Dahim, M.H. (2016). Scenario Based Agriculture Land Use for Achieving Sustainable Irrigation Water Requirements in Saudi Arabia: A Case Study of Najran Region. Journal of current research in science. 4(1), 17 - 31.

Perera, A.C.S. (2015). Impact of climate variability on water availability and paddy productivity in the "Hakwatuna Oya" irrigation scheme in Sri Lanka. Unpublished Thesis. Postgraduate Institute of Agriculture, University of Peradeniya.

Punyawardana, B.V.R. (2008). Rainfall and Agro-ecological Zones of Sri Lanka, Department of Agriculture, Sri Lanka.

Punyawardena, B.V.R. (2012). Impact of Climate Change on Agriculture in Sri Lanka and Possible Response Strategies. IPS-CLIMATEnet. Available at http://climatenet.blogspot.com/2012/09/impact-of-climate-change-on agriculture 17.html. Accessed on 14.06.2016. 
Rathnayake, M.U.K. (2011). Water management for rice in paddy production technology. Training program for subject matter officers, Training center, Rice Research Institute, Bathalegoda, Sri Lanka.

Rowshon, M.K., Amin, M.S.M., Mojid, M., Yaji. M. (2014). Estimated Evapotranspiration of Rice Based on Pan Evaporation as a Surrogate to Lysimeter Measurement. Paddy and Water Environment. 12(1), 35 - 41.

Shahid, S. (2010). Impact of Climate Change on Irrigation Water Demand of Dry Season Boro Rice in Northwest Bangladesh. Journal of Climatic Change. 105(3), 433 - 453.

Shen, Y., Li, S., Chen, Y., Qi, Y. and Zhang, S. (2013). Estimation of Regional Irrigation Water Requirement and Water Supply Risk in the Arid Region of Northwestern China 19892010. Agricultural Water Management. 128, 55 - 64.

Schewea, J., Heinkea, J., Gertena, D., Haddeland, I., etc. (2014). Multimodel assessment of water scarcity under climate change. Proceeding of the National Academy of Science of the United States of America (PNAS). 111(9), 3245 - 3250.

Smith, M. (1992). CROPWAT: A Computer Program for Irrigation Planning and Management. Food and Agriculture Organization, Italy.

Tukimat, N.A., and Harun. S. (2012). Comparative Methods in Measuring the Irrigation Water Needs at Muda Irrigation Scheme, Kedah. ULTRA Engineer. 1(1), 29 - 33.

Vairavamoorthy, K., Gorantiwar, S.D. and Pathirana, A. (2008). Managing urban water supplies in developing countries - Climate change and water scarcity scenarios. Physics and Chemistry of the Earth, Parts A/B/C. 33(5), 330 - 339.

Wilby, R.L., Dawson, C.W. and Barrow, E.M. (2002). SDSM - A Decision Support Tool for the Assessment of Regional Climate Change Impacts. Environmental Modelling \& Software. $17(2), 147-159$.

Zainal, Z., Shamsudin, M.N., Mohamed, Z.A., Adam, S.U. and Kaffashi, S. (2014). Assessing the Impacts of Climate Change on Paddy Production in Malaysia. Research Journal of Environmental Sciences. 8(6), 331 - 341. 